\title{
Mechanically Treated Fly Ash from Fluidized Bed Combustion of Peat, Wood, and Wastes in Concrete
}

\author{
Katja Ohenoja $^{1}\left(\mathbb{D} \cdot\right.$ Valter Wigren $^{2} \cdot$ Jan Österbacka ${ }^{3} \cdot$ Mirja Illikainen $^{1}$
}

Received: 20 August 2018 / Accepted: 11 February 2019 / Published online: 20 February 2019

(c) The Author(s) 2019

\begin{abstract}
Fly ash generation in fluidized bed combustion (FBC) is a critical issue in many countries due to its disposal is becoming increasingly restricted and expensive. Because of this, there is a demand for applications in which these types of fly ashes could be utilized efficiently. One promising use for FBC fly ashes is as a cement replacement material in mortar and concrete. The current concrete regulations do not allow the use FBC fly ash as a supplementary cementitious material, but it can be expected to be included in the standards in the future. The properties of FBC fly ashes typically do not fulfill the values set in the standards as such. This study aimed to establish whether the properties of fly ashes from FBC of peat, wood, and wastes can be modified by mechanical classification and grinding so that they meet the requirements of the standards. The sulfate and chloride content, the sum of the main components ( $\mathrm{Si}, \mathrm{Al}, \mathrm{Fe})$, and the fineness of material were analyzed before and after the classification and grinding processes. In addition, the mortar specimens were prepared by using the processed fly ash as a cement replacement material. It was found that air jet classification is an effective fractionating method for fly ashes that effectively removes sulfate and chloride into fine fraction. Classified and ground fly ashes are potential alternative cement replacement materials. It is possible to achieve $80 \%$ of the control sample's compressive strength and $90 \%$ of the control sample's flexural strength for mortars containing $20 \%$ of classified and ground FBC fly ashes.
\end{abstract}

\section{Graphical Abstract}

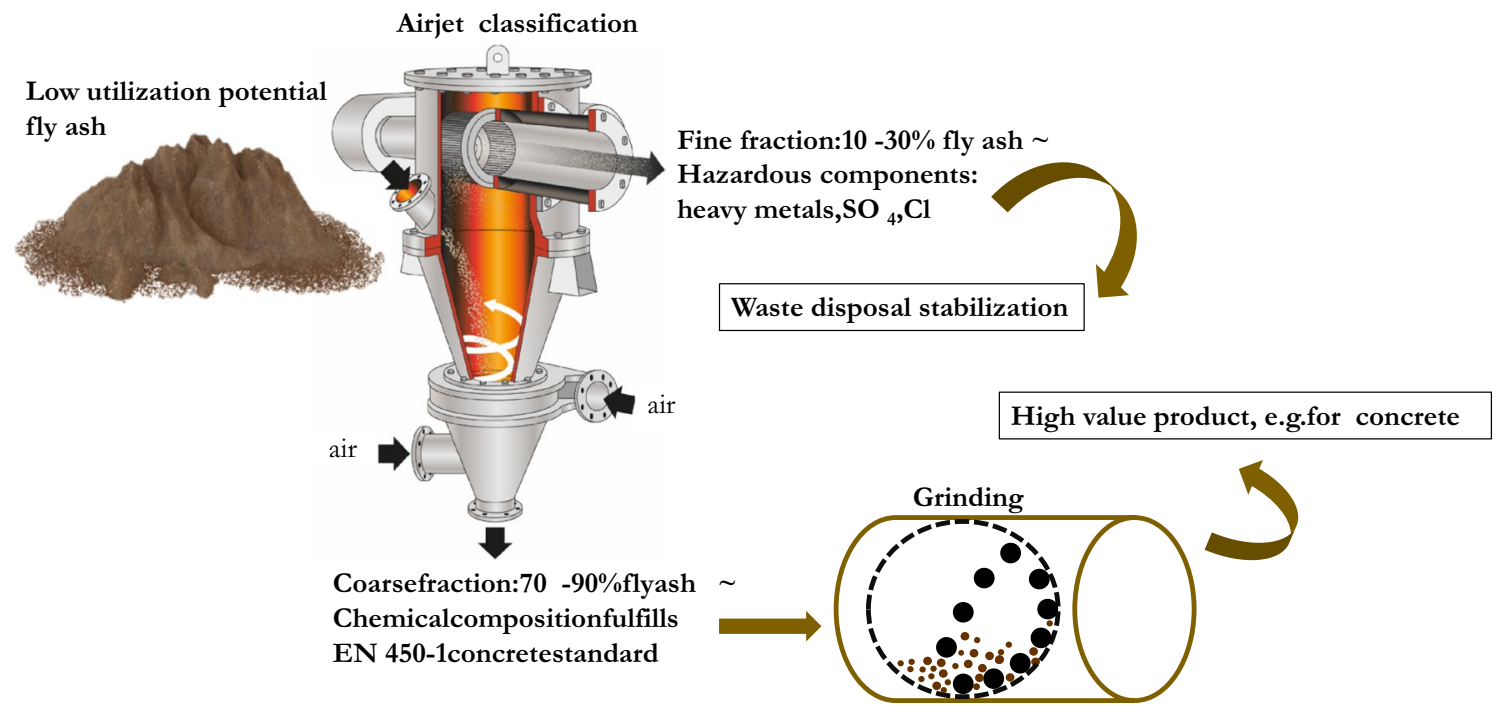

Keywords Biomass ash $\cdot$ Concrete $\cdot$ Fractionating $\cdot$ Wood ash $\cdot$ Wood waste ash $\cdot$ Sustainability

Extended author information available on the last page of the article 


\section{Statement of Novelty}

This study aimed to establish whether the utilization potential of fly ashes from FBC of peat, wood, and wastes can be improved in concrete by mechanical classification and grinding, which is not done earlier. We found that it is possible to modify these fly ashes to fulfill concrete standards. Usually it is thought that fly ashes from fluidized bed combustion are not suitable for standardized concrete, but this study shows that with treatments it is possible.

\section{Introduction}

Biomass is a sustainable energy source used to produce electricity and heat, and its use will continue to increase. The use of renewable energy is encouraged by the political goals of the European Union (EU), such as the "2030 climate and energy framework" that has set a target to increase the share of renewable energy sources to cover at least $27 \%$ of EU energy consumption by 2030 [1]. Biomass can be co-fired with peat and different wastes, such as recycling waste, which contains different packing materials, or side-streams from the food and paper industries. Among the available combustion methods, fluidized bed combustion (FBC) is efficient and common due to its ability to utilize low-grade fuels with fluctuating quality, composition, and moisture content, or mixtures of fuels, in situ capture of SOx, and low NOx emission [2]. However, the fly ash originating from FBC has thus far had limited utilization potential even though millions of tons of this type of fly ash are generated annually in Europe alone and this amount is expected to increase. Fly ash generation is a critical issue in many countries, especially when considering that disposal is becoming increasingly restricted and expensive, contributing to a demand for applications in which fly ashes could be utilized efficiently.

One interesting category of use for FBC fly ashes is as a cement replacement material or an aggregate in concrete. In addition to prevent disposal, using fly ash as a cement replacement material means a significant reduction in $\mathrm{CO}_{2}$ emissions related to industrial cement production from traditional raw materials (limestone and clay), and the preservation of natural resources can also be achieved. There are many promising studies that have investigated the use of FBC fly ash as a cement replacement material [3-13]. However, the use of FBC or biomass fly ashes as a partial cement replacement material is not allowed by the American standard ASTM 618 [14] or the European standard EN 450-1 [15], which are the standards governing the use of fly ashes as mineral admixtures in concrete. EN 450-1 applies to ashes originating from pulverized combustion where the coal content must be over $60 \%$, or over $50 \%$ when coal combustion takes place with pure wood. However, it is reasonable to expect that in the future, extension of the current regulations surrounding the use of fly ash in concrete should be limited to those fly ashes meeting the physical and chemical requirements (see Table 1) as specified in the ASTM C 618 or EN 450-1 standards. Therefore, these limit values can be used now to provide a guideline for fly ash utilization in concrete.

The European standard EN 450-1 sets several required chemical and physical properties for fly ash to be used in concrete. When concerning biomass fly ash, the most critical properties are sulfate and chloride content and the sum of the main components, namely $\mathrm{SiO}_{2}, \mathrm{Al}_{2} \mathrm{O}_{3}$, and $\mathrm{Fe}_{2} \mathrm{O}_{3}$. According to that standard, chloride content must be $<0.1 \%$, sulfate $<3 \%$, and the sum of the main components over $70 \%$. Peat fly ash fulfilled the requirements of these standards without any treatment [16], but in contrast, biomass and waste fly ash often require some sort of treatment to ensure that they adhere to the limits set by the governing standards [17-22]. To comply with the limit values set by the standards, waterwashing treatment for biomass fly ashes has been carried out $[17,18]$. However, this procedure requires water and energy for drying. Therefore, mechanical classification is one interesting option to improve fly ash chemical composition without the use of water, as there is a relationship between fly ash particle size and heavy metal, $\mathrm{Cl}^{-}$and $\mathrm{SO}_{4}^{2}$ content [23-31]. It has been found that the utilization potential of fly ash from biomass and waste combustion can be significantly improved with mechanical classification [30]. However, the particle size distribution of classified coarse fraction and its behavior as a cement replacement material is not studied. Therefore, this study aimed to establish whether the properties of fly ashes from FBC of peat, wood, and wastes can be modified by mechanical classification and grinding so that they meet

Table 1 Chemical and physical characteristics for fly ashes to be used in concrete applications (SFS-EN 450-1 and ASTM C 618)

\begin{tabular}{lll}
\hline Characteristic & \multicolumn{2}{l}{ Limit value (\%) } \\
\cline { 2 - 3 } & SFS EN 450-1 & ASTM C 618 \\
\hline Loss on ignition at $950{ }^{\circ} \mathrm{C}$ & $\mathrm{A}<5, \mathrm{~B}<7, \mathrm{C}<9$ & $<6$ \\
$\mathrm{SiO}_{2}, \mathrm{Al}_{2} \mathrm{O}_{3}, \mathrm{Fe}_{2} \mathrm{O}_{3}$ & $>70$ & $\mathrm{~F}>70, \mathrm{C}>50$ \\
$\mathrm{Chloride}$ & $<0.1$ & - \\
Sulfate as $\mathrm{SO}_{3}$ & $<3$ & $<5$ \\
Free $\mathrm{CaO}$ & $<1.5$ & - \\
Tot. alkalis $\left(\mathrm{Na}_{2} \mathrm{O}+\mathrm{K}_{2} \mathrm{O}\right)$ & $<5$ & - \\
$\mathrm{MgO}$ & $<4$ & - \\
$\mathrm{P}_{2} \mathrm{O}_{5}$ & $<5$ & - \\
Fineness $(45 \mu \mathrm{m})$ & $\mathrm{S}<12, \mathrm{~N}<40$ & $<34$ \\
Activity index 28 days & $>75$ & - \\
\hline
\end{tabular}


the requirements of the standards. Fly ash composition after classification and grinding was compared to limit values set by the European EN 450-1 standard. The effect of sulfate and chloride content, the sum of the main components, and fly ash fineness for mortar properties were investigated.

\section{Materials and Methods}

\section{Fly Ashes}

Fly ashes from three different Finnish power plants utilizing bubbling fluidized bed boilers were studied. The power plants used different mixtures of fuels; therefore, the fly ash samples differed in their properties. Fuel composition of the first fly ash sample (FA1) was 70\% forest residues and 30\% peat; the second fly ash sample (FA2) was $60 \%$ forest residues, $30 \%$ recycling waste, and $10 \%$ sludge from the papermaking industry; the third fly ash sample (FA3) was $40 \%$ peat, $50 \%$ forest residues, and $10 \%$ recycled wood waste. Forest industry residues contains felling waste, like branch, bark and leaf. Recycling waste contains packing material waste, such as plastic (not PVC), carton, paper, and wood collected from industrial and retail outlets. Recycled wood waste is collected from industrial and retail outlets. Sludge from the papermaking industry contains cellulose fibers, pigments and fillers from papermaking process. Fly ash samples were collected from the first electrostatic precipitator unit in $10 \mathrm{~L}$ buckets.

\section{Materials for Mortars}

The cement used in this study was Portland cement type CEM I 52.5 R-SR5 from Finnsementti (Finland). Sand used as an aggregate material was sieved natural silicon sand from Fescon (Finland). A particle size distribution of the sand is the following: $\mathrm{d}_{10}=440 \mu \mathrm{m}, \mathrm{d}_{25}=630 \mu \mathrm{m}, \mathrm{d}_{50}=880 \mu \mathrm{m}$, $\mathrm{d}_{75}=1200 \mu \mathrm{m}$ and $\mathrm{d}_{90}=1940 \mu \mathrm{m}$ measured by laser diffraction technique. A polycarboxylate-based superplasticizer agent (Sem®Flow ELE 20, Semtu) was used to adjust the consistency of mortar mixtures.

\section{Methods}

\section{Analysis of Fly Ashes}

The particle size distribution of the fly ash samples reported as a volumetric median size $\left(\mathrm{d}_{50}\right)$ was measured with the laser diffraction technique (Beckman Coulter LS 13320) using the Fraunhofer model and the wet procedure using water. A specific surface area measurement was based on the physical adsorption of gas molecules on a solid surface using Micrometrics ASAP 2020, and the results were reported as a BET isotherm. The main chemical components of fly ash were determined using an Omnian Pananalytics Axiosmax $4 \mathrm{kV} \mathrm{X-ray} \mathrm{fluorescence} \mathrm{(XRF)} \mathrm{from} \mathrm{a} \mathrm{melt-fused} \mathrm{tablet.}$ The melt-fused tablet was produced from $1.5 \mathrm{~g}$ of fly ash melted at $1150{ }^{\circ} \mathrm{C}$ with $7.5 \mathrm{~g}$ of X-ray Flux Type 66:34 (66\% $\mathrm{LiB}_{4} \mathrm{O}_{7}$ and $34 \% \mathrm{LiBO}_{2}$ ). Field-emission scanning electron microscopy (FESEM, Zeiss Ultra Plus) was used to visualize the fly ash samples. The FESEM sample was prepared by adding a thin layer of fly ash on the coal sticker. The samples were sputter-coated with platinum, and a $10 \mathrm{kV}$ voltage was used when imaging the samples.

\section{Classification}

The air jet classification method (Multiprocessing System, Hosokawa Alpine, Augsburg, Germany) was used to fractionate fly ash samples into fine and coarse fractions, as presented in [30]. Classification rotor speed of $2000 \mathrm{rpm}$ and air flow of $75 \mathrm{~m}^{3} / \mathrm{h}$ was used, and fine material shares from 15 to $30 \%$ were achieved depending on the fly ash. The achieved coarse and fine fractions were collected for weighing and elemental analysis. The classified coarse fly ash fractions are further abbreviated as FA1_C, FA2_C, and FA3_C.

\section{Grinding}

Half of the classified coarse fly ash fractions (FA1_C, FA2_C, and FA3_C) were ground by an impact mill with one rotating and one stationary pin disc (Laboratory Fine Impact Mill 100 UPZ-II, Hosokawa Alpine, Augsburg, Germany). The pin mill was operated with the rotational speed of $22,000 \mathrm{rpm}$, corresponding to a tip speed of $160 \mathrm{~m} / \mathrm{s}$. After grinding, three new samples for mortar tests were achieved: FA1_CG, FA2_CG, and FA3_CG.

\section{Mortar Preparation}

The control sample was prepared using cement, tap water, and sand. Original fly ashes, coarse fractions of fly ashes from classification before (FA1_C, FA2_C, and FA3_C) and after grinding (FA1_CG, FA2_CG, and FA3_CG) were used to replace $20 \%$ of the cement in the mortar samples. Preparation of mortar samples was done according to cement standard EN 196-1 [32] with slight modifications. Modifications included the flow table test done before molding the samples. Additionally, adjustments were made to mortar consistency using a superplasticizer in the samples. Consistencies of fresh mortar mixtures were evaluated using a flow table test described in a mortar testing standard [33]. The consistency was evaluated to ensure the proper rheology of the mortar mixtures (i.e., spread values $17 \mathrm{~mm} \pm 2 \mathrm{~mm}$ ), and to determine whether a superplasticizer is necessary to use. The designs of the mortar mixtures are presented in Table 2. 
Table 2 Mortar mix design

\begin{tabular}{llllll}
\hline & $\begin{array}{l}\text { Cement } \\
(\mathrm{g})\end{array}$ & $\begin{array}{l}\text { Fly ash } \\
(\mathrm{g})\end{array}$ & $\begin{array}{l}\text { Sand } \\
\text { aggregate } \\
(\mathrm{g})\end{array}$ & Water $(\mathrm{g})$ & $\begin{array}{l}\text { Super } \\
\text { plasticizer } \\
(\mathrm{m})\end{array}$ \\
\hline Control & 450 & 0 & 1350 & 225 & 0 \\
FA1_C & 360 & 90 & 1350 & 225 & 0 \\
FA1_CG & 360 & 90 & 1350 & 225 & 0 \\
FA2_C & 360 & 90 & 1350 & 225 & 0 \\
FA2_CG & 360 & 90 & 1350 & 225 & 0 \\
FA3_C & 360 & 90 & 1350 & 225 & 1 \\
FA3_CG & 360 & 90 & 1350 & 225 & 0 \\
\hline
\end{tabular}

All mortar specimens fabricated were cured in water at room temperature $\left(20^{\circ} \mathrm{C}\right)$ for 28 days prior to being tested.

\section{Mortar Strength Measurements}

Flexural strength was measured from $40 \times 40 \times 160-\mathrm{mm}$ mortar prisms, and broken halves were used for unconfined compressive strength measurements. The strengths of the samples were measured after 28 days of curing using a Zwick testing machine with a maximum load of $100 \mathrm{kN}$ employing a loading force of $2.4 \mathrm{kN} / \mathrm{s}$. The reported strength of mortar is the average of the replica specimens tested: three replicas for flexural strength and six replicas for compressive strength were measured.

\section{Results and Discussion}

\section{Fly ash Properties}

The chemical compositions of the original fly ashes were mainly $\mathrm{CaO}$ and $\mathrm{SiO}_{2}$, but the fly ashes also contained high percentages of $\mathrm{Al}_{2} \mathrm{O}_{3}$ and $\mathrm{Fe}_{2} \mathrm{O}_{3}$ (Table 3). All fly ashes contained small percentages of $\mathrm{Na}_{2} \mathrm{O}, \mathrm{K}_{2} \mathrm{O}$, and $\mathrm{P}_{2} \mathrm{O}_{5}$, except for FA3, which contained as much as $6.5 \%$ of $\mathrm{K}_{2} \mathrm{O}$. FA2 and FA3 had a high sulfate content of over $6 \%$. FA1 and FA2 had similar particle size: the median particle size was $45.0 \mu \mathrm{m}$ for FA1 and $46.5 \mu \mathrm{m}$ for FA2. FA3 was much smaller, having a median particle size of $22.1 \mu \mathrm{m}$. The BET surface area varied substantially between fly ashes, from 1.0 to $4.5 \mathrm{~m}^{2} / \mathrm{g}$. When comparing the chemical composition of fly ashes to SFS-EN 450-1 limit values (see Table 1), it can be noted that the sulfate and chloride content of FA1 are at an acceptable level, but levels are remarkably high for FA2 and FA3. $\mathrm{P}_{2} \mathrm{O}_{5}$ and $\mathrm{MgO}$ contents are below the limits for all fly ashes. The sum of $\mathrm{SiO}_{2}, \mathrm{Al}_{2} \mathrm{O}_{3}$, and $\mathrm{Fe}_{2} \mathrm{O}_{3}$ is below the limit (70\%) for all studied fly ashes: $68 \%$ for FA1, 56.4\% for FA2, and $53.8 \%$ for FA3. A FESEM images of original fly ash samples are presented in Fig. 1. Fly ash particles have mainly an irregular shape, but the particle shape changes from spherical to fibrous. Differences between ash samples can not be seen reliably from FESEM images.

\section{Classification of the Fly Ashes}

Through air jet classification, the FBC fly ash utilization potential for concrete use can be increased significantly. Air jet classification is an efficient separation process that separates components into fine and coarse fractions so that hazardous components tend to concentrate to a fine fraction
Table 3 Chemical and physical properties of studied fly ashes

\begin{tabular}{lrrrlll}
\hline & FA1 & FA2 & FA3 & FA1_C & FA2_C & FA3_C \\
\hline $\mathrm{CaO}(\%)$ & 16.0 & 23.0 & 21.1 & 15.1 & 14.5 & 13.8 \\
$\mathrm{SiO}_{2}(\%)$ & 52.2 & 39.4 & 43.8 & 53.7 & 49.7 & 56.5 \\
$\mathrm{Al}_{2} \mathrm{O}_{3}(\%)$ & 11.0 & 12.1 & 7.4 & 11.1 & 13.6 & 8.8 \\
$\mathrm{Fe}_{2} \mathrm{O}_{3}(\%)$ & 4.8 & 4.9 & 2.6 & 4.7 & 5.3 & 2.8 \\
$\mathrm{Na}_{2} \mathrm{O}(\%)$ & 2.1 & 2.9 & 2.1 & 2.1 & 2.9 & 2.2 \\
$\mathrm{~K}_{2} \mathrm{O}(\%)$ & 2.9 & 2.4 & 6.5 & 2.9 & 2.6 & 5.9 \\
$\mathrm{P}_{2} \mathrm{O}_{5}(\%)$ & 1.7 & 1.3 & 3.0 & 1.6 & 0.9 & 1.8 \\
$\mathrm{MgO}(\%)$ & 3.5 & 3.1 & 3.4 & 3.3 & 2.2 & 2.3 \\
$\mathrm{SO}(\%)$ & 1.7 & 6.9 & 6.3 & 1.4 & 2.4 & 2.2 \\
$\mathrm{Cl}(\%)$ & 0.1 & 0.4 & 0.3 & 0.1 & 0.1 & 0.1 \\
free-CaO $(\%)$ & 1.1 & 3.9 & 3.2 & - & - & - \\
Loss on ignition $950{ }^{\circ} \mathrm{C}(\%)$ & 3.2 & 0.7 & 5.4 & 2.9 & 3.9 & 3.3 \\
Particle size $\mathrm{d}_{50}(\mu \mathrm{m})$ & 45.0 & 46.5 & 22.1 & 160.5 & 229.8 & 206.8 \\
$\mathrm{BET}$ surface $\operatorname{area~}\left(\mathrm{m}^{2} / \mathrm{g}\right)$ & 4.5 & 1.0 & 2.3 & - & - & - \\
\hline
\end{tabular}




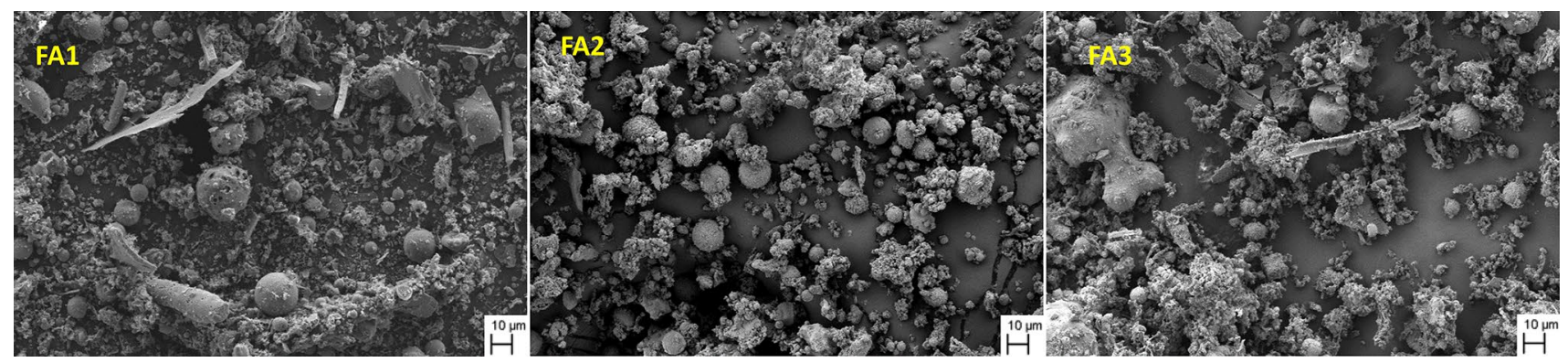

Fig. 1 FESEM images of original fly ashes

[30]. According to mass balance, when some elements concentrate to a fine fraction, other elements must concentrate to a coarse fraction. The work of [30] showed that when FBC fly ashes are classified with air jet classification, $\mathrm{CaO}$ is concentrated to a fine fraction, whereas $\mathrm{SiO}_{2}$ and $\mathrm{Al}_{2} \mathrm{O}_{3}$ are concentrated to a coarse fraction. Both sulfate and chloride have been found to concentrate to a fine fraction with high selectivity, which means that if mass share for fine fraction is $20 \%$, up to $70 \%$ of the total sulfate and chloride content can concentrate to a fine fraction [30]. The removed fine material share depended on the original fly ash properties, i.e., particle size and shape: with the used classification parameters (rotor speed of $2000 \mathrm{rpm}$ and air flow of $75 \mathrm{~m}^{3} / \mathrm{h}$ ), fine fraction removal was $15 \%$ from FA1, $31 \%$ from FA2, and $22 \%$ from FA3.

According to SFS-EN 450-1, for fly ash to be used in concrete, the sum of the contents of $\mathrm{SiO}_{2}, \mathrm{Al}_{2} \mathrm{O}_{3}$, and $\mathrm{Fe}_{2} \mathrm{O}_{3}$ shall not be $<70 \%$ by mass. Therefore, the concentration of $\mathrm{SiO}_{2}, \mathrm{Al}_{2} \mathrm{O}_{3}$, and $\mathrm{Fe}_{2} \mathrm{O}_{3}$ to coarse fraction and $\mathrm{CaO}$ to fine fraction is an advantage when considering concrete applications for fly ash. For the fly ash samples studied here, the sum of $\mathrm{SiO}_{2}, \mathrm{Al}_{2} \mathrm{O}_{3}$, and $\mathrm{Fe}_{2} \mathrm{O}_{3}$ increased with air jet classification (Fig. 2). The sum increased from 68 to $71 \%$ for FA1, from 56 to $69 \%$ for FA2, and from 54 to $68 \%$ for FA3.

The sulfate content of fly ashes (Fig. 3a) can be decreased significantly and clearly to an acceptable level by removing $30 \%$ as fine fraction from FA2 and 22\% from FA3. However, for FA1, it can be noted that air jet classification was not necessary according to the sulfate content. As with $\mathrm{SO}_{3}$, chloride content (Fig. 3b) for FA1 was also at an acceptable level originally, making classification unnecessary. Instead, for FA2 and FA3, chloride content could be decreased significantly to a nearly acceptable level by removing $30 \%$ as fine fraction from FA2 and $22 \%$ from FA3.

\section{Grinding of the Fly Ashes}

Typically, fly ashes are quite fine-grained and easy to grind [34]. However, when fly ash is classified and coarse fraction is taken for further processing, grinding becomes

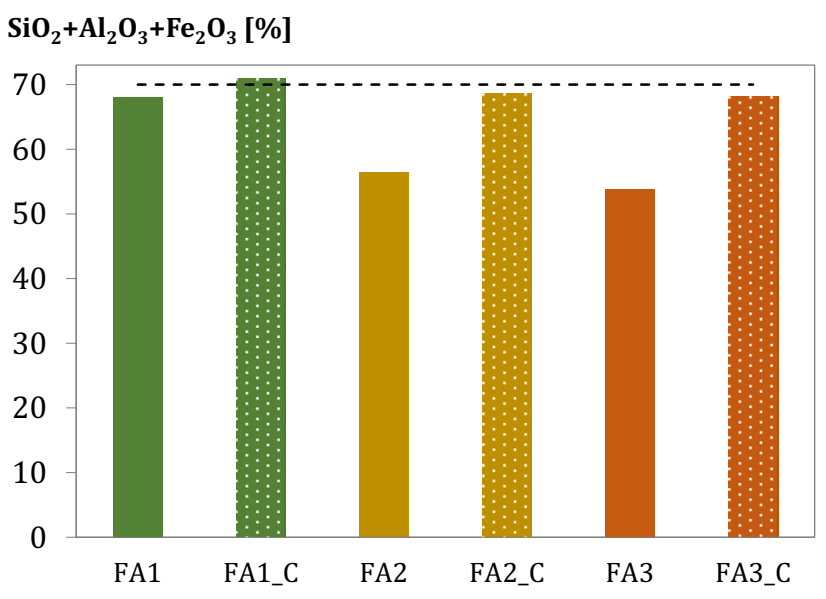

Fig. 2 Sum of $\mathrm{SiO}_{2}, \mathrm{Al}_{2} \mathrm{O}_{3}$, and $\mathrm{Fe}_{2} \mathrm{O}_{3}$ for original and classified fly ashes. Dashed line represents the minimum value for the sum according to EN 450-1

more important. FA1 and FA2 had median particle sizes of approximately $45 \mu \mathrm{m}$ and FA3's median particle size was approximately $22 \mu \mathrm{m}$. After air jet classification, the particle sizes of coarse fly ash fractions were around $200 \mu \mathrm{m}$, but this could be further reduced by grinding to around $30 \mu \mathrm{m}$ for all fly ashes.

After grinding, all classified fly ashes (FA1_CG, FA2 CG, and FA3_CG) fulfilled the Class $\mathrm{N}$ fineness requirement (Fig. 4). Particle sizes of fly ashes are presented in Fig. 4 as a cumulative $>45 \mu \mathrm{m}$ because standard EN 450-1 uses this value as a fineness measurement. According to EN 450-1, Category $\mathrm{N}$ means that the fineness shall not exceed $40 \%$ by mass, and category $\mathrm{S}$ means that the fineness shall not exceed $12 \%$ by mass. Original and classified FA1 and FA2 did not meet Class $\mathrm{N}$ or $\mathrm{S}$ requirements. However, FA3 originally fulfilled the standard. The particle size distributions of all fly ash samples was measured using laser diffraction method (see Fig. 5a-c). As can be seen classification increased the particle size distribution for all ashes, but grinding reduced the distribution to finer 

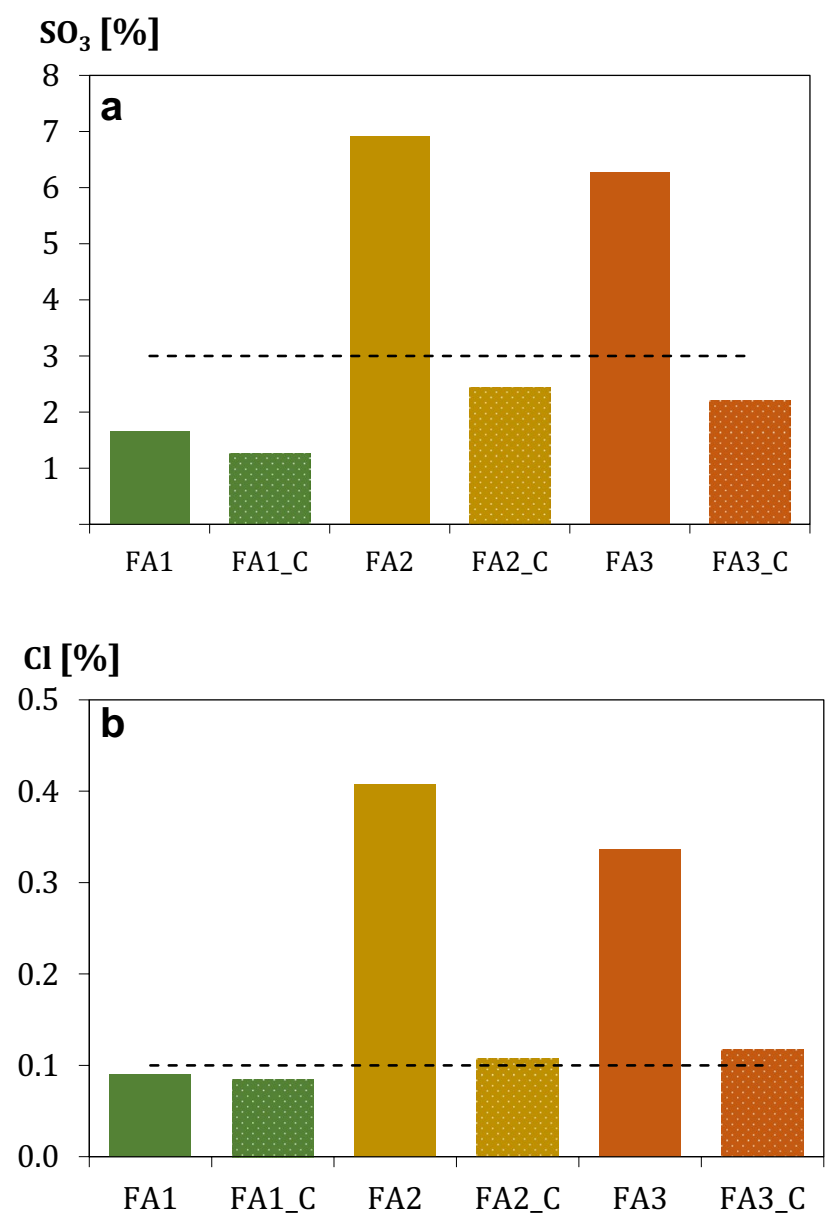

Fig. 3 a Sulfate and $\mathbf{b}$ chloride content for original and classified fly ashes. Dashed line represents the maximum values according to $\mathrm{EN}$ 450-1

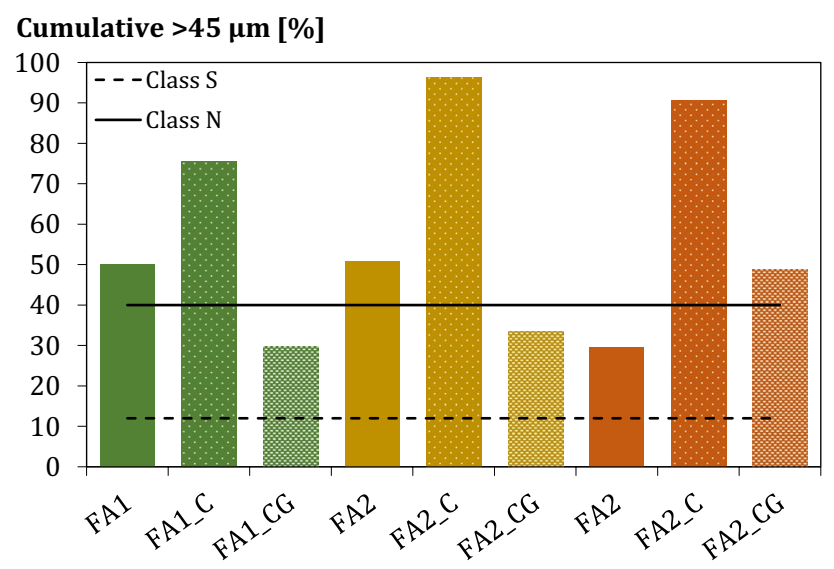

Fig. 4 Cumulative $>45 \mu \mathrm{m}$ measured with laser diffraction method. Dashed line represents limit values for Class $\mathrm{N}$ and $\mathrm{S}$ fly ash according to EN 450-1 size compared to original. Exception to this is FA3 which classified fraction is coarser and it most probably explains the need for superplasticizer (Table 2).

\section{Mortar Experiments}

Mortars containing 20 mass- $\%$ of fly ashes did not achieve the same flexural strength as the control, but it can be seen that grinding improved the strength to close to the control's level for all studied fly ashes (Fig. 6). Flexural strength for the control sample (100\% OPC) after 28 days was 6.7 MPa. When only classified coarse fraction was used as a cement replacement material, around a $20 \%$ loss in flexural strength was incurred. This means that coarse fly ash particles are not reactive and are only working as a filler material. Instead, when using classified and ground FA1 and FA3 as cement replacement materials, only a $10 \%$ decrease in strength was observed. Mortar containing FA2 did not attain strength as high as FA1 or FA3 in any case.

Mortars containing 20 mass- $\%$ of fly ashes did not achieve the same compressive strength as the control, but it can be seen that grinding improved the strength to close to the required $75 \%$ of the control strength for FA1 and FA3 (Fig. 7). Standard EN 450-1 sets the limit for the activity index to be $75 \%$ of the control sample for mortars containing cement replacement material. Therefore, the dashed line in Fig. 7 indicates $75 \%$ strength compared to the control sample. The control sample (100\% of OPC) had a compressive strength of $50 \mathrm{MPa}$. Mortar containing the FA2 sample did not attain strength as high as FA1 or FA3. When only classified coarse fraction of FA1 and FA2 was used as a cement replacement material, around a $40 \%$ loss in compressive strength was incurred. Mortar containing $20 \%$ of FA3 had higher strength of around $75 \%$ of the control, and that value did not increase significantly when ground FA3 was used. It can be seen that grinding of coarse fraction is valuable for FA1: an over $20 \%$ increase in mortar compressive strength was possible to achieve.

When comparing these results to earlier published work $[9,16,29,35]$, it can be seen that the achieved activity indexes are lower for classified fly ashes (Fig. 7) than for original fly ashes. The reason for this is probably the lower reactivity of classified ashes: calcium and sulfur are important components for FBC fly ash reactivity [16, 35 ], and in this present work, many of those components were removed from the fraction used to replace cement. Because of this, aiming to fulfill concrete standards is questionable for FBC fly ash if significant strength loss is not wanted. Therefore, long-term durability tests for mortar and concrete containing un-fractioned FBC fly ashes are needed in the future. 

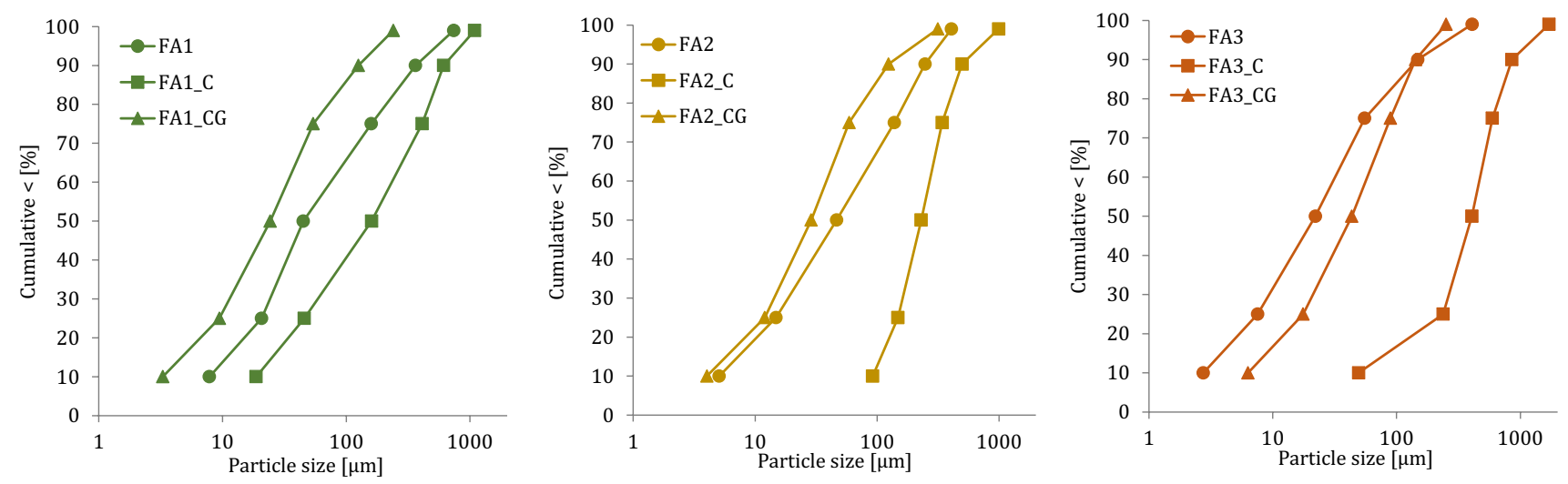

Fig. 5 Particle size distributions of fly ash samples: a FA1, b FA2 and c FA3

\section{$28 \mathrm{~d}$ flexural strength [MPa]}

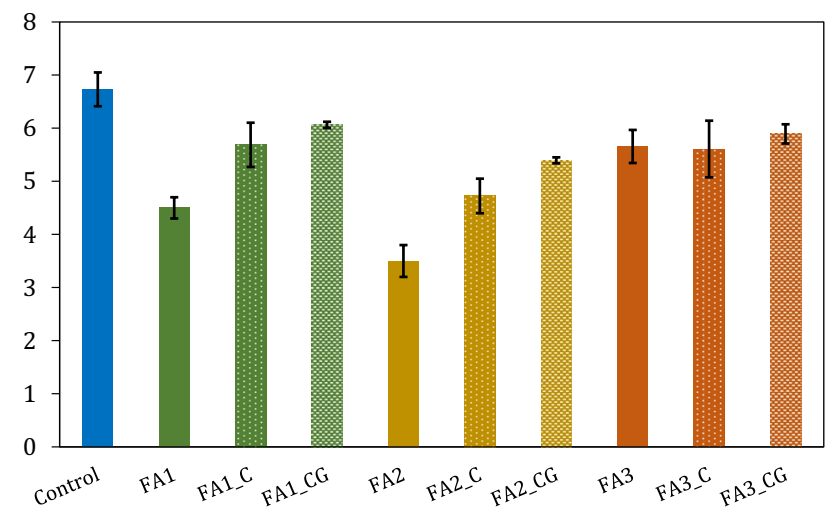

Fig. 628 days flexural strengths of mortars containing classified and ground fly ashes with $20 \%$ cement replacement

\section{$28 \mathrm{~d}$ compressive strength [MPa]}

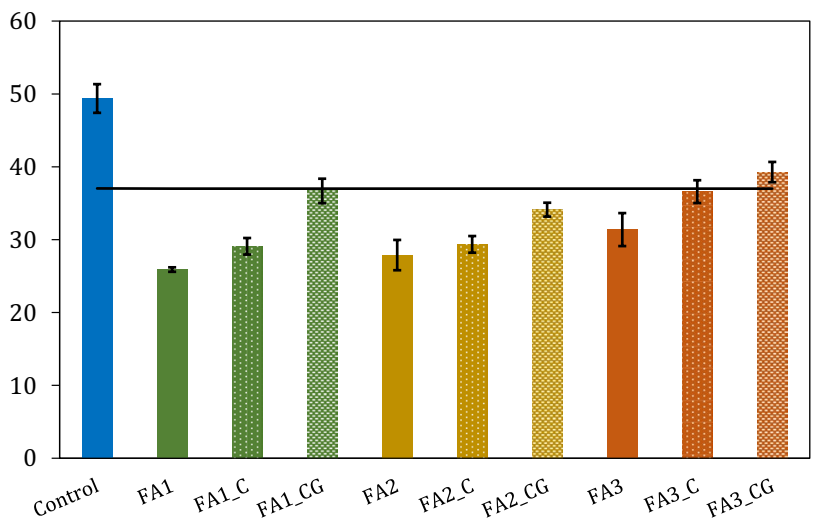

Fig. 728 days compressive strengths of mortars containing classified and ground fly ashes with $20 \%$ cement replacement. Dashed line represents $75 \%$ strength of the control sample

\section{Conclusions}

The utilization potential of fly ashes from FBC of peat, wood, and wastes in concrete can be increased significantly through air jet classification and grinding. Air jet classification effectively removes sulfate and chloride into fine fraction. The coarse fraction contains mostly the desired chemical components $\left(\mathrm{SiO}_{2}, \mathrm{Al}_{2} \mathrm{O}_{3}\right.$ and $\left.\mathrm{Fe}_{2} \mathrm{O}_{3}\right)$, but it is too coarse to be utilized as it is. Desired particle size distribution is achieved by tumbling ball milling. Classified and ground fly ashes are potential alternative cement replacement materials because they fulfill the requirements of the EN 450-1 concrete standard for chemical composition, particle fineness and activity index of mortar. It is possible to achieve $80 \%$ of the control sample's compressive strength and $90 \%$ of the control sample's flexural strength for mortars containing $20 \%$ of classified and ground FBC fly ashes. Therefore, these type of fly ashes can be utilized in construction industry instead of landfilling and at the same time, $\mathrm{CO}_{2}$ emissions of cement industry can be reduced.

Acknowledgements Open access funding provided by University of Oulu including Oulu University Hospital. This study was supported by the Finnish Funding Agency for Technology and Innovation and the following Finnish companies: Boliden Harjavalta Oy, Ekokem Palvelu Oy, Fortum Power and Heat Oy, Helen Oy, Jyväskylän Energia Oy, Kemira Chemicals Oy, Metsä Board Oyj, Napapiirin Energia ja Vesi Oy, Nordkalk Oy Ab, Paroc Group Oy, SSAB Europe Oy, Stora Enso Oyj, UPM-Kymmene Oyj, and Valmet Technologies Oy. We would like to thank Mr. Jarno Karvonen, Mr. Jani Österlund, and Ms. Maria Tomperi for their contributions to the laboratory work.

OpenAccess This article is distributed under the terms of the Creative Commons Attribution 4.0 International License (http://creativeco mmons.org/licenses/by/4.0/), which permits unrestricted use, distribution, and reproduction in any medium, provided you give appropriate credit to the original author(s) and the source, provide a link to the Creative Commons license, and indicate if changes were made. 


\section{References}

1. European Commission: Communication from the commission to the European Parliament, The Council, The European Economic and Social Committee and the Committee of the Regions. A policy framework for climate and energy in the period from 2020 to 2030. (2014)

2. Patel, A., Basu, P., Acharya, B.: An investigation into partial capture of $\mathrm{CO}_{2}$ released from a large coal/petcoke fired circulating fluidized bed boiler with limestone injection using its fly and bottom ash. J. Environ. Chem. Eng. 5, 667-678 (2017). https://doi. org/10.1016/j.jece.2016.12.047

3. Behr-Andres, C.B., Hutzler, N.J.: Characterization and use of fluidized-bed-combustion coal ash. J. Environ. Eng. U. S. 120, 1488-1506 (1994). https://doi.org/10.1061/ (ASCE)0733-9372(1994)120:6(1488)

4. Chang, Y.-M., Lin, L.-K., Chang, T.-C.: A preliminary assessment on reusage of flyash emitted from fluidized bed incineration of sludge cake. Resour. Conserv. Recycl. 20, 245-266 (1997). https ://doi.org/10.1016/S0921-3449(97)00019-0

5. Chen, X., Gao, J., Yan, Y., Liu, Y.: Investigation of expansion properties of cement paste with circulating fluidized bed fly ash. Constr. Build. Mater. 157, 1154-1162 (2017). https://doi. org/10.1016/j.conbuildmat.2017.08.159

6. Chi, M.: Synthesis and characterization of mortars with circulating fluidized bed combustion fly ash and ground granulated blastfurnace slag. Constr. Build. Mater. 123, 565-573 (2016). https:// doi.org/10.1016/j.conbuildmat.2016.07.071

7. Havlica, J., Brandstetr, J., Odler, I.: Possibilities of utilizing solid residues from pressured fluidized bed coal combustion (PSBC) for the production of blended cements. Cem. Concr. Res. 28, 299-307 (1998). https://doi.org/10.1016/S0008-8846(97)00258-5

8. Rissanen, J., Ohenoja, K., Kinnunen, P., Romagnoli, M., Illikainen, M.: Milling of peat-wood fly ash: effect on water demand of mortar and rheology of cement paste. Constr. Build. Mater. 180, 143-153 (2018). https://doi.org/10.1016/j.conbuildma t.2018.05.014

9. Rissanen, J., Ohenoja, K., Kinnunen, P., Illikainen, M.: Partial replacement of portland-composite cement by fluidized bed combustion fly ash. J. Mater. Civ. Eng. (2017). https://doi.org/10.1061/ (ASCE)MT.1943-5533.0001899

10. Sata, V., Jaturapitakkul, C., Kiattikomol, K.: Influence of pozzolan from various by-product materials on mechanical properties of high-strength concrete. Constr. Build. Mater. 21, 1589-1598 (2007). https://doi.org/10.1016/j.conbuildmat.2005.09.011

11. Sebök, T., Śimoník, J., Kulísek, K.: The compressive strength of samples containing fly ash with high content of calcium sulfate and calcium oxide. Cem. Concr. Res. 31, 1101-1107 (2001). https ://doi.org/10.1016/S0008-8846(01)00506-3

12. Šiler, P., Bayer, P., Sehnal, T., Kolářová, I., Opravil, T., Šoukal, F.: Effects of high-temperature fly ash and fluidized bed combustion ash on the hydration of Portland cement. Constr. Build. Mater. 78, 181-188 (2015). https://doi.org/10.1016/j.conbuildma t.2015.01.032

13. Wu, T., Chi, M., Huang, R.: Characteristics of CFBC fly ash and properties of cement-based composites with CFBC fly ash and coal-fired fly ash. Constr. Build. Mater. 66, 172-180 (2014). https ://doi.org/10.1016/j.conbuildmat.2014.05.057

14. ASTM, C.: 618-12a: Standard specification for coal fly ash and raw or calcined natural pozzolan for use as a mineral admixture in concrete, http://blocksjordan.net/Portals/0/C\%20618\%20-\%20 00\%20\%20_QZYXOC0WMA_.pdf, (2012)

15. EN 450-1: SFS-EN 450-1 Fly ash for concrete. Definition, specifications and conformity criteria., (2012)
16. Ohenoja, K., Wigren, V., Österbacka, J., Illikainen, M.: Applicability of fly ash from fluidized bed combustion of peat, wood, or wastes to concrete. Waste Biomass Valoriz. (2018). https://doi. org/10.1007/s12649-018-0319-5

17. Berra, M., Mangialardi, T., Paolini, A.E.: Reuse of woody biomass fly ash in cement-based materials. Constr. Build. Mater. 76, 286-296 (2015). https://doi.org/10.1016/j.conbuildma t.2014.11.052

18. Doudart de la Grée, G.C.H., Florea, M.V.A., Keulen, A., Brouwers, H.J.H.: Contaminated biomass fly ashes-Characterization and treatment optimization for reuse as building materials. Waste Manag. 49, 96-109 (2016). https://doi.org/10.1016/j. wasman.2015.12.023

19. Rajamma, R., Ball, R., Tarelho, L., Allen, G., Labrincha, J., Ferreira, V.: Characterisation and use of biomass fly ash in cementbased materials. J. Hazard. Mater. 172, 1049-1060 (2009)

20. Sarabèr, A.J.: Co-combustion and its impact on fly ash quality; full-scale experiments. Fuel Process. Technol. 128, 68-82 (2014). https://doi.org/10.1016/j.fuproc.2014.06.026

21. Wang, S.: Compressive strengths of mortar cubes from hydrated lime with cofired biomass fly ashes. Constr. Build. Mater. 50, 414-420 (2014). https://doi.org/10.1016/j.conbuildma t.2013.09.045

22. Wang, S., Llamazos, E., Baxter, L., Fonseca, F.: Durability of biomass fly ash concrete: Freezing and thawing and rapid chloride permeability tests. Fuel. 87, 359-364 (2008). https://doi. org/10.1016/j.fuel.2007.05.027

23. Camerani, M.C., Steenari, B.-M., Sharma, R., Beckett, R.: Cd speciation in biomass fly ash particles after size separation by centrifugal SPLITT. Fuel. 81, 1739-1753 (2002). https://doi. org/10.1016/S0016-2361(02)00092-3

24. Davison, R.L., Natusch, D.F.S., Wallace, J.R., Evans, C.A.: Trace elements in fly ash. Dependence of concentration on particle size. Environ. Sci. Technol. 8, 1107-1113 (1974). https://doi. org/10.1021/es60098a003

25. Lanzerstorfer, C.: Air classification: Potential treatment method for optimized recycling or utilization of fine-grained air pollution control residues obtained from dry off-gas cleaning high-temperature processing systems. Waste Manag. Res. 33, 1041-1044 (2015). https://doi.org/10.1177/0734242X15597997

26. Lanzerstorfer, C.: Cyclone fly ash from a grate-fired biomass combustion plant: dependence of the concentration of various components on the particle size. Fuel Process. Technol. 131, 382-388 (2015). https://doi.org/10.1016/j.fuproc.2014.12.010

27. Lanzerstorfer, C.: Investigation of the contamination of a fly ash sample during sample preparation by air classification. Int. J. Environ. Sci. Technol. 12, 1437-1442 (2015). https://doi. org/10.1007/s13762-014-0586-Z

28. Obernberger, I., Biedermann, F., Widmann, W., Riedl, R.: Concentrations of inorganic elements in biomass fuels and recovery in the different ash fractions. Biomass Bioenergy. 12, 211-224 (1997). https://doi.org/10.1016/S0961-9534(96)00051-7

29. Ohenoja, K., Körkkö, M., Wigren, V., Österbacka, J., Illikainen, M.: Fly ash classification efficiency of electrostatic precipitators in fluidized bed combustion of peat, wood, and forest residues. J. Environ. Manage. 206, 607-614 (2018). https://doi.org/10.1016/j. jenvman.2017.10.047

30. Ohenoja, K., Körkkö, M., Wigren, V., Österbacka, J., Illikainen, M.: Increasing the utilization potential of fly ashes from fluidized bed combustion by mechanical treatments. Int. J. Environ. Sci. Technol. (2018). https://doi.org/10.1007/s13762-018-1812-x

31. Orava, H., Nordman, T., Kuopanportti, H.: Increase the utilisation of fly ash with electrostatic precipitation. Miner. Eng. 19, 1596-1602 (2006). https://doi.org/10.1016/j.mineng.2006.07.002

32. SFS (Finnish Standards Association): "Methods of testing cement. Part 1: Determination of strength" SFS-EN 196-1:2016:en. (2016) 
33. EN 1015-3: Methods of test for mortar for masonry. Determination of consistence of fresh mortar (by flow table). European Committee for Standardization., (1999)

34. Ohenoja, K., Tanskanen, P., Peltosaari, O., Wigren, V., Österbacka, J., Illikainen, M.: Effect of particle size distribution on the self-hardening property of biomass-peat fly ash from a bubbling fluidized bed combustion. Fuel Process. Technol. 148, 60-66 (2016). https://doi.org/10.1016/j.fuproc.2016.02.023

35. Illikainen, M., Tanskanen, P., Kinnunen, P., Körkkö, M., Peltosaari, O., Wigren, V., Österbacka, J., Talling, B., Niinimäki,
J.: Reactivity and self-hardening of fly ash from the fluidized bed combustion of wood and peat. Fuel. 135, 69-75 (2014). https:// doi.org/10.1016/j.fuel.2014.06.029

Publisher's Note Springer Nature remains neutral with regard to jurisdictional claims in published maps and institutional affiliations.

\section{Affiliations}

\section{Katja Ohenoja $^{1}$ (I) $\cdot$ Valter Wigren $^{2} \cdot$ Jan Österbacka ${ }^{3} \cdot$ Mirja Illikainen $^{1}$}

Katja Ohenoja

katja.ohenoja@oulu.fi

1 Fibre and Particle Engineering, Faculty of Technology, University of Oulu, PO Box 4300, 90014 Oulu, Finland
Renotech Oy, Sampsankatu 4B, PO Box 20520, Turku, Finland

3 Fortum Waste Solutions Oy, Kuulojankatu 1, PO Box 181, 11101 Riihimäki, Finland 